\title{
ЭПИДЕМИЯ COVID-19 И ОТВЕТ ЗДРАВООХРАНЕНИЯ В РАЗНЫХ СТРАНАХ
}

\author{
ГУЗЕЛЬ УЛУМБЕКОВА, АРГИШТИ ГИНОЯН, ИВАН ПЕТРАЧКОВ
}

\begin{abstract}
Задача данного исследования - выявить сочиально-экономические и демографические факторы, а также характеристики системы здравоохранения и оперативные меры, принятые в борьбе с новой коронавирусной инфекцией COVID-19, которые способствовали скорейтей стабилизации эпидемической обстановки в разных странах. Для сравнения выбраны 14 стран: Белоруссия, Великобритания, Германия, Испания, Италия, Канада, Китай, Норвегия, Польша, США, Российская Федерация, Тайвань, Швеция и Южная Корея.

Проведен анализ эпидемических (число выявленных случаев COVID-19 в расчете на 1 млн населения, летальность и смертность от этой инфекции на 100 mыс. населения, число проведенных диагностических тестов), демографических (средний возраст населения, плотность населения, ожидаемая продолжительность жизни - ОПЖ) и экономических (валовой внутренний продукт ВВП на душу населения) показателей и оценено состояние системы здравоохранения (общие и государственные расходы на здравоохранение в процентах к ВВП; обеспеченность стационарными койками и практикующими врачами; модель государственного финансирования здравоохранения $и$ управления им).
\end{abstract}

Показано, что главными факторами, способствующими успеху в борьбе с распространением новой коронавирусной инфекции COVID-19, являются раннее реагирование и решительнье действия; цุентрализация управления регионами и санитарно-эпидемиологической службой во главе с министром здравоохранения; наличие единой для страны стратегии действий; проведение массового тестирования и быстрое отслеживание контактов зараженных; централизованное распределение средств индивидуальной защитты, лекарств и других расходных материалов, а также мониторинг потребности в них; использование передовых информационных технологий; достаточные мощности системы здравоохранения (наличие резервного коечного фонда и медищинских кадров); ежедневная информаџионная работа с населением, которая осуществляется специалистами и министром здравоохранения.

Ключевые слова: пандемия COVID-19, летальность и смертность от COVID-19, диагностическое тестирование COVID-19, меры по борьбе с пандемией COVID-19, государственное финансирование здравоохранения, обеспеченность стационарными койками, обеспеченность практикующими врачами, иентрализация управления здравоохранением.

ГУЗЕЛЬ ӘРНСТОВНА УЛУМБЕКОВА (vshouz@vshouz.ru), ВЫСШАЯ ШКОЛА ОРГАНИЗАЦИИ И УПРАВЛЕНИЯ ЗДРАВООХРАНЕНИЕМ - КОМПЛЕКСНЫЙ МЕДИЦИНСКИЙ КОНСАЛТИНГ (ВШОУЗ-КМК), ФЕДЕРАЛЬНОЕ ГОСУДАРСТВЕННОЕ АВТОНОМНОЕ ОБРАЗОВАТЕЛЬНОЕ УЧРЕЖДЕНИЕ ВЫСШЕГО ОБРАЗОВАНИЯ «РОССИЙСКИЙ НАЦИОНАЛЬНЫЙ ИССЛЕДОВАТЕЛЬСКИЙ МЕДИЦИНСКИЙ УНИВЕРСИТЕТ ИМЕНИ Н.И. ПИРОГОВА» МИНИСТЕРСТВА ЗДРАВООХРАНЕНИЯ РФ, РОССИЯ.

АРГИШТИ БАГРАТОВИЧ ГИНОЯН (agrio1q89@hotmail.com), ВЫСШАЯ ШКОЛА ОРГАНИЗАЦИИ И УПРАВЛЕНИЯ ЗДРАВООХРАНЕНИЕМ - КОМПЛЕКСНЫЙ МЕДИЦИНСКИЙ КОНСАЛТИНГ (ВШОУЗ-КМК), ФЕДЕРАЛЬНОЕ ГОСУДАРСТВЕННОЕ АВТОНОМНОЕ ОБРАЗОВАТЕЛЬНОЕ УЧРЕЖДЕНИЕ ВЫСШЕГО ОБРАЗОВАНИЯ «ФИНАНСОВЫЙ УНИВЕРСИТЕТ ПРИ ПРАВИТЕЛЬСТВЕ РОССИЙСКОЙ ФЕДЕРАЦИИ», РОССИЯ.

ИВАН ВАЛЕРЬЕВИЧ ПЕТРАЧКОВ (ecrb2007@уandeX.ru), ФЕДЕРАЛЬНОЕ ГОСУДАРСТВЕННОЕ АВТОНОМНОЕ ОБРАЗОВАТЕЛЬНОЕ УЧРЕЖДЕНИЕ ВЫСШЕГО ОБРАЗОВАНИЯ «ФИНАНСОВЫЙ УНИВЕРСИТЕТ ПРИ ПРАВИТЕЛЬСТВЕ РОССИЙСКОЙ ФЕДЕРАЦИИ», РОССИЯ.

СТАТЬЯ ПОСТУПИЛА В РЕДАКЦИЮ В ИЮНЕ 2020 Г. 


\section{ЭПИДЕМИЧЕСКИЕ ПОКАЗАТЕЛИ ПО НОВОЙ КОРОНАВИРУСНОЙ ИНФЕКЦИИ COVID-19}

Характеристика эпидемической ситуации дана по РФ и следующим 14 странам: Белоруссия, Великобритания, Германия, Испания, Италия, Канада, Китай, Норвегия, Польша, США, Тайвань, Швеция и Южная Корея по состоянию на 17 июня 2020 г. Проанализированы следующие показатели: число выявленных случаев инфекции (всего и в расчете на 1 млн населения), число умерших от данной инфекции (всего, летальность и смертность на 100 тыс. населения), число проведенных тестов (всего, в расчете на 1 тыс. населения и на число выявленных зараженных). Все данные представлены в таблице в конце статьи.

Из всех рассматриваемых стран самое большее число выявленных случаев приходится на США (2 138 тыс. случав), затем следуют в порядке убывания: Россия (545 тыс.), Великобритания (298 тыс.), Испания (244 тыс.), Италия (238 тыс.), Германия (187 тыс.), Канада (99 тыс.), Китай (84 тыс.), Белоруссия (55 тыс.) Швеция (53 тыс.), Польша (30 тыс.) Южная Корея (12 тыс.), Норвегия (9 тыс.), Тайвань (0,4 тыс.). Этот показатель в расчете на 1 млн населения в России более чем на 65\% выше, чем в Германии, Канаде, Норвегии, и в 16 и более раз выше, чем в Южной Корее, Китае и Тайване, но ниже, чем в Белоруссии, Великобритании, Италии, Испании, США и Швеции (рисунок 1).

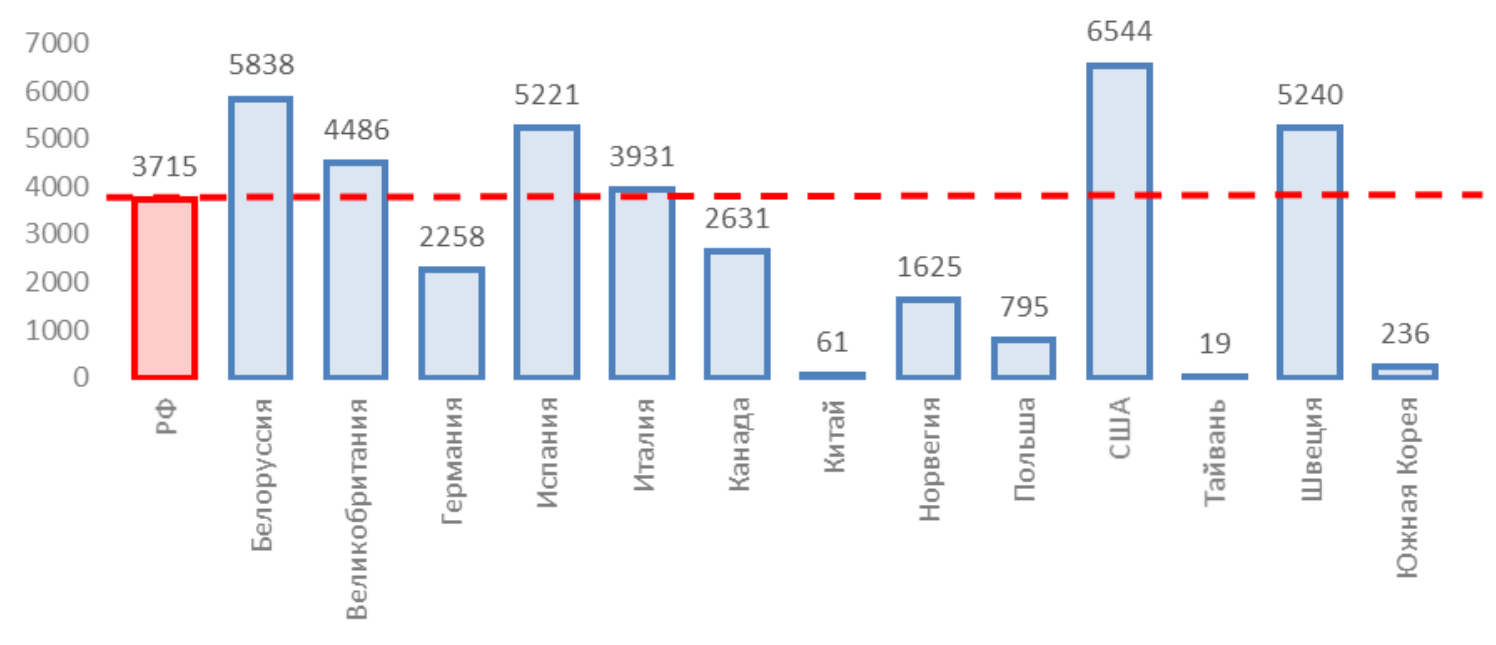

Рисунок 1. Число выявленных случаев COVID-19 в разных странах на 1 млн населения по состоянию на 17 июня 2020 г.

Источник: Расчеты ВШОУЗ на основе данных Роспотребнадзора; базы данных Johns Hopkins University.

Общее число умерших от новой короноварусной инфекции COVID-19 самое высокое в США (117 тыс.), далее в порядке убывания следуют Великобритания (42 тыс.), Италия (34,4 тыс.), Испания (27,1 тыс.), Германия (8,8 тыс.), Канада (8,2 тыс.), Россия (7,3 тыс.), Швеция (4,9 тыс.), Китай (4,6 тыс.), Польша (1,3 тыс.), Белоруссия и Южная Корея (по 0,3 тыс.), Норвегия (0,2 тыс.), Тайвань (7 случаев). 
Ежедневное число умерших в среднем за последние 4 дня (с 13 по 17 июня) самое высокое в США (574 случаев), далее в порядке убывания: Россия (142), Великобритания (122), Италия (46), Канада (41), Швеция (21), Польша (13), Германия (12), Белоруссия (5), Китай (2), Южная Корея (1). В Испании, Норвегии и Тайване нет смертей.

Самые низкие показатели летальности (отношение числа умерших к числу выявленных случаев COVID-19) из всех рассматриваемых стран наблюдаются в Белоруссии, России и Тайване (рисунок 2).

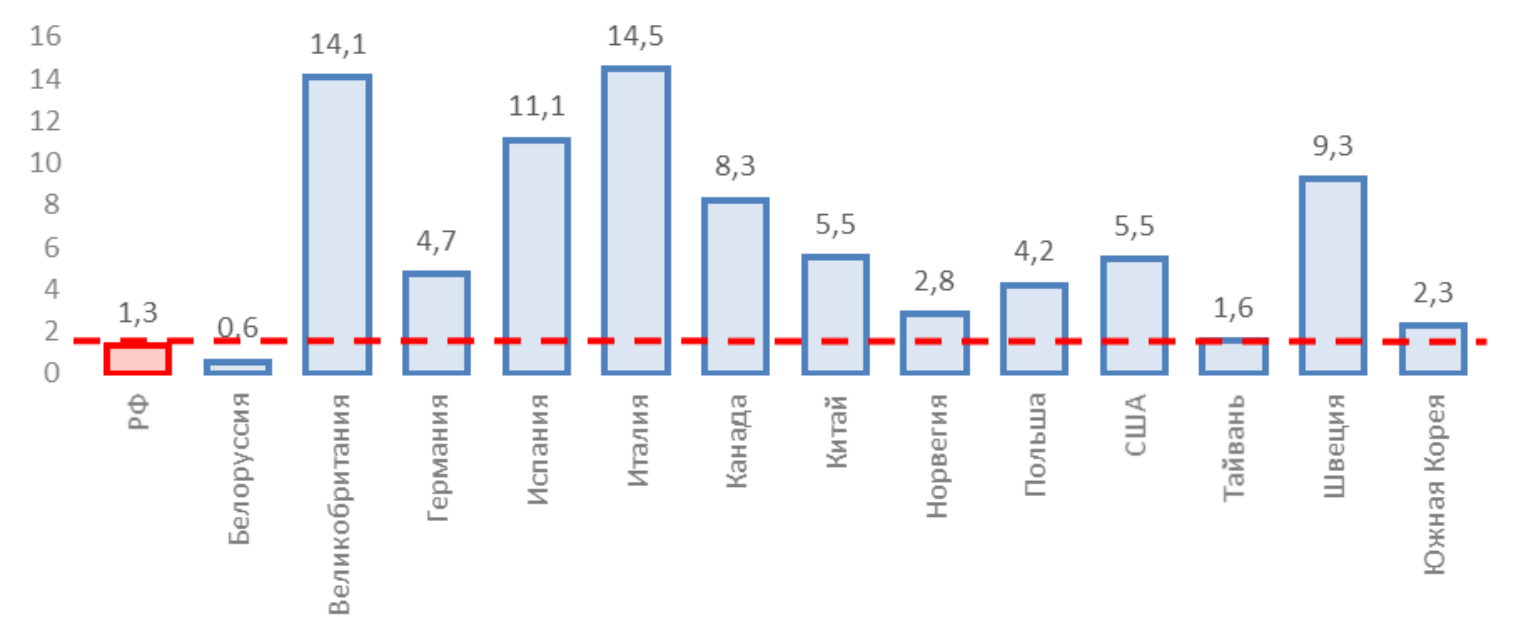

\section{Рисунок 2. Летальность от COVID-19 в разных странах}

Источник: Расчеты ВШОУЗ на основе данных Роспотребнадзора; базы данных Johns Hopkins University.

В России смертность от COVID-19 в расчете на 100 тыс. населения выше, чем в Китае, Тайване, Польше и Белоруссии, но ниже, чем в остальных странах (рисунок 3 ).

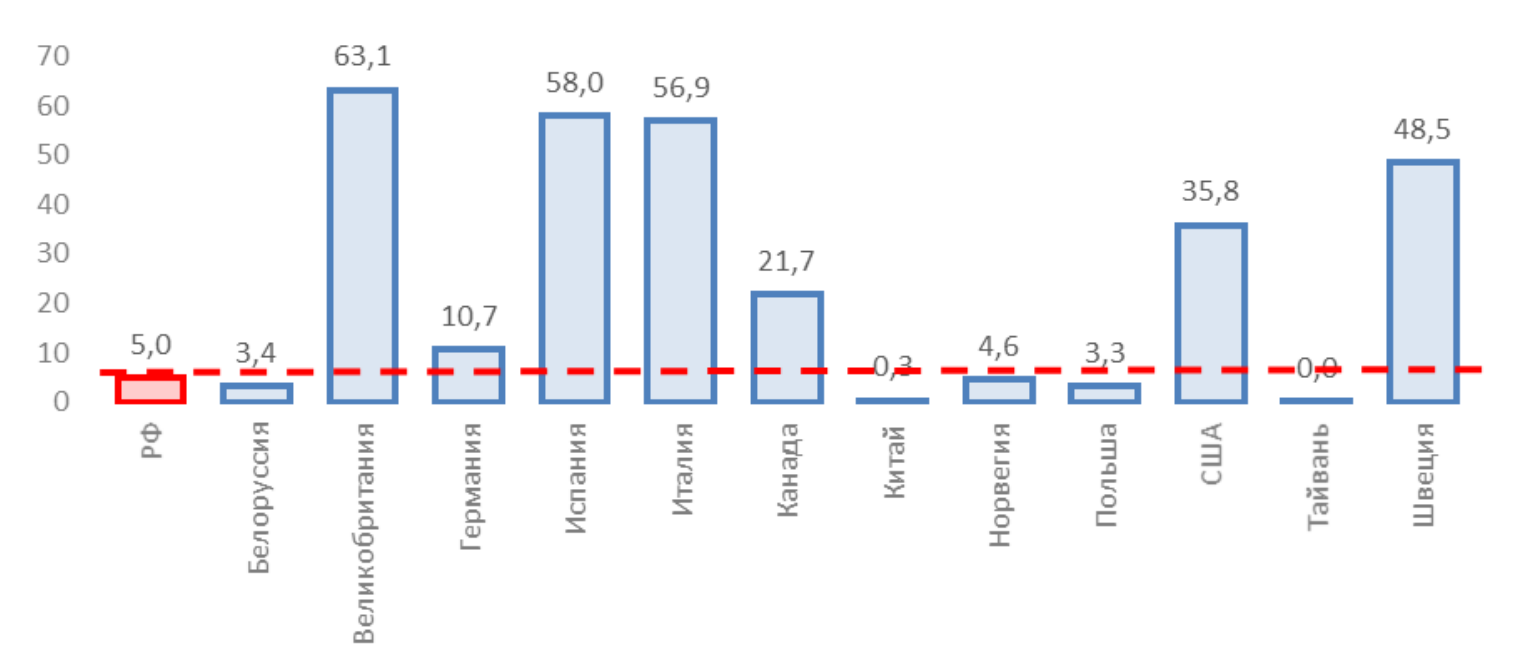

Рисунок 3. Смертность от COVID-19 на 100 тыс. населения в разных странах

Источник: Расчеты ВШОУЗ на основе данных Роспотребнадзора; базы данных Johns Hopkins University.

На рисунках 4-6 представлены данные по объемам лабораторного диагностического тестирования на выявление зараженных COVID-19. Самое большое число тестов сделано в 
Китае и США - соответственно 26 и 24 млн, далее следуют Россия (15,7 млн) и другие страны (рисунок 4). По этому показателю в расчете на 1000 населения Россия значительно опережает все рассмотренные страны. В России на выявление 1 зараженного приходится 29 тестов, что практически соответствует уровню европейских стран, США и Канады (от 7 до 34 тестов), но значительно ниже, чем в рассматриваемых странах Восточной Азии, где этот показатель варьируется от 93 до 308 на 1000.

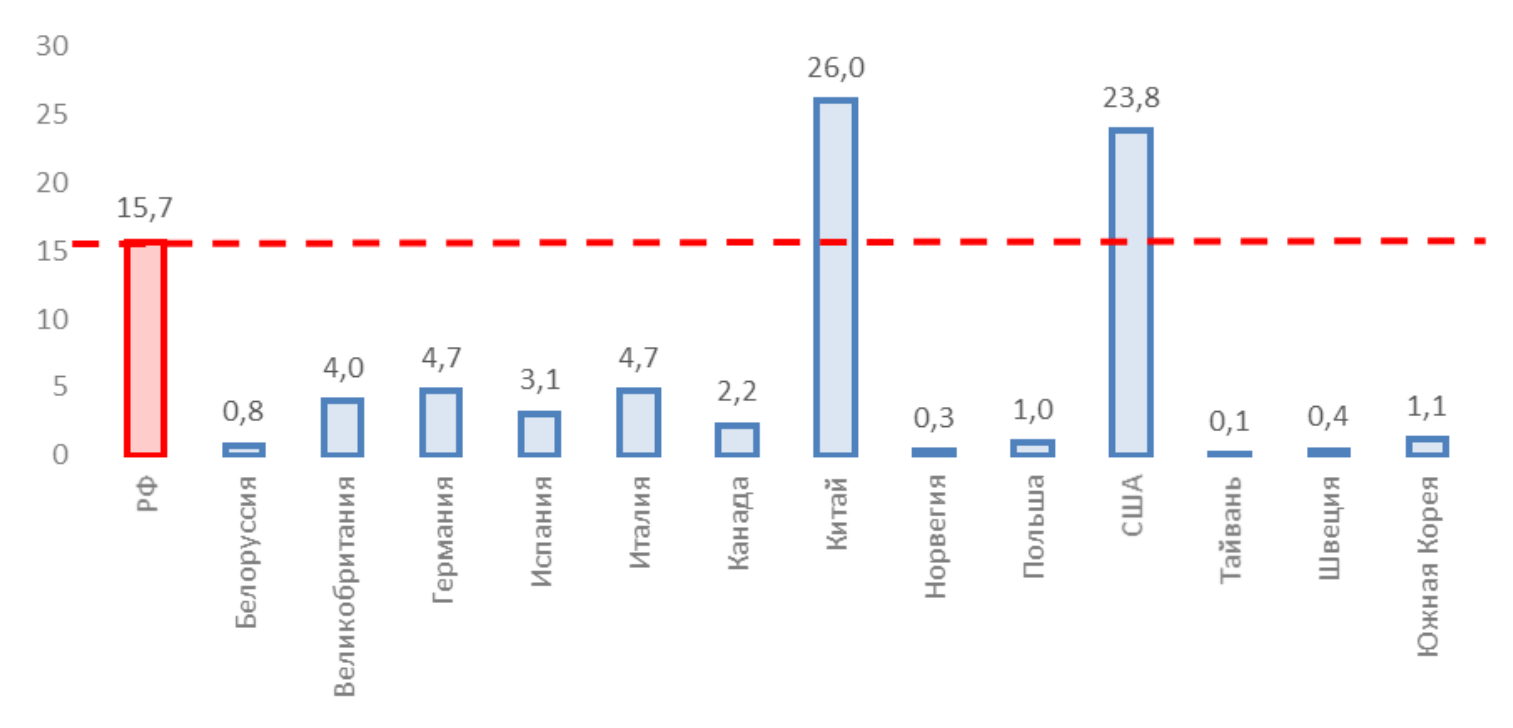

Рисунок 4. Число проведенных диагностических тестов для выявления COVID-19 в разных странах (всего), млн

Источник: Расчеты ВШОУЗ на основе данных Роспотребнадзора; базы данных Johns Hopkins University.

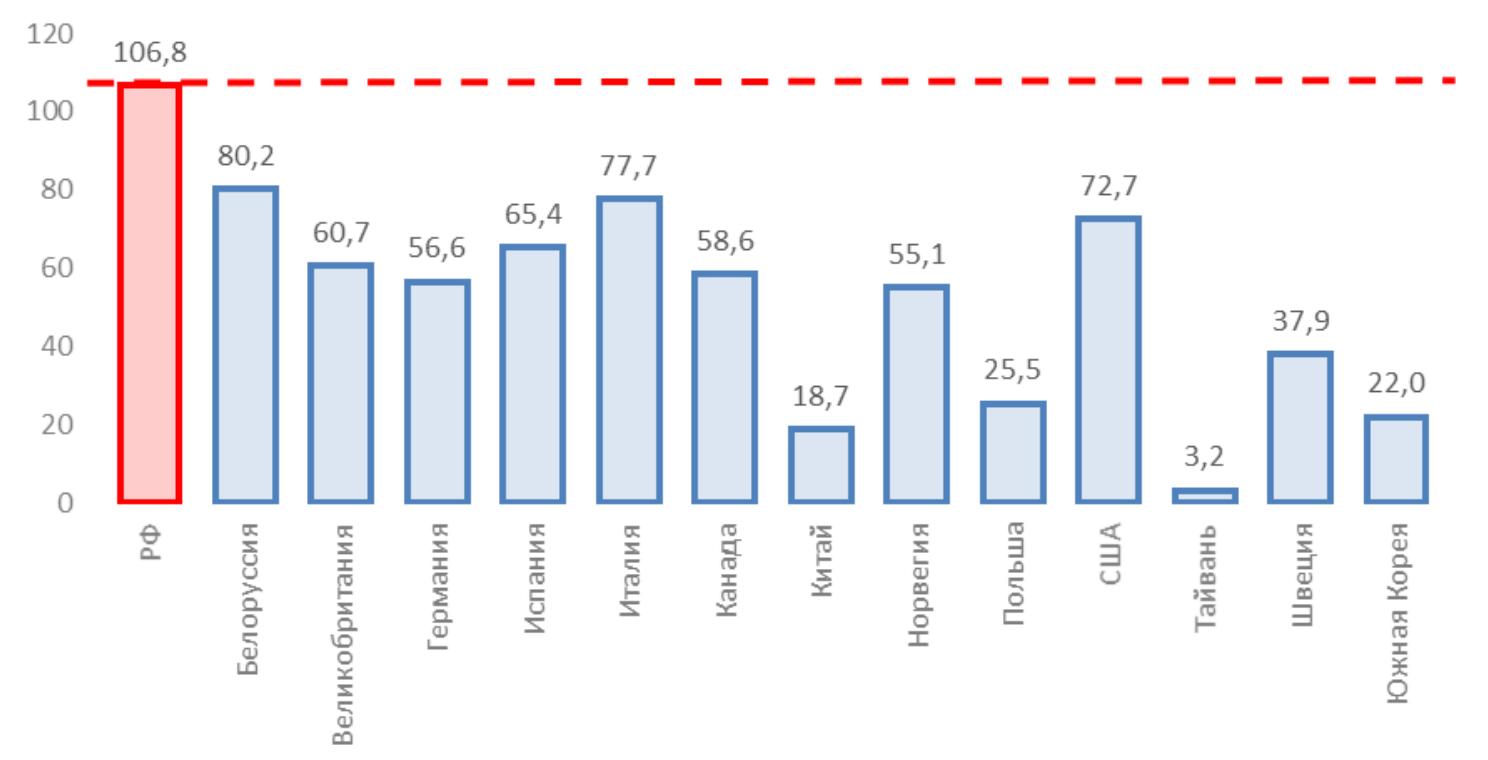

\section{Рисунок 5. Число проведенных тестов на COVID-19 в разных странах в расчете на 1000 населения}

Источник: Расчеты ВШОУЗ на основе данных Роспотребнадзора; базы данных Johns Hopkins University. 


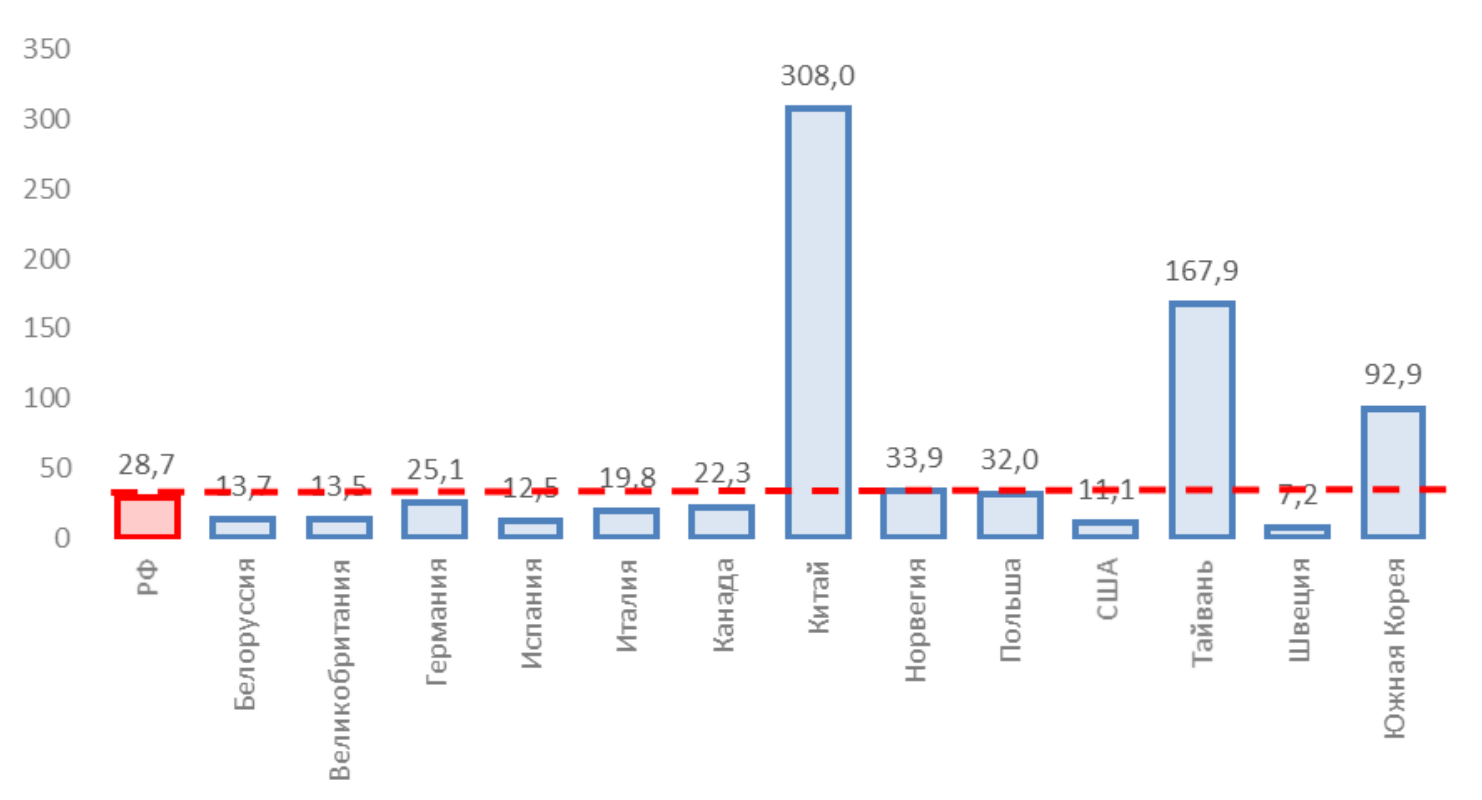

\section{Рисунок 6. Число проведенных тестов на COVID-19 в разных странах на 1 инфицированного}

Источник: Расчеты ВШОУЗ на основе данных Роспотребнадзора; базы данных Johns Hopkins University.

Таким образом, по общему числу выявленных случаев заражений новой коронавирусной инфекцией ситуация в РФ не очень благоприятная: среди 14 рассматриваемых стран по абсолютному числу случаев она находится на 2-м, а в расчете на 1 млн населения - на 7-м месте. При этом летальность от этой инфекции в России одна из самых низких среди всех рассматриваемых стран, что, возможно, частично связано с особенностями регистрации смертей. Несмотря на это в России смертность от COVID-19 выше, чем в странах Восточной Азии. Самыми успешными странами, с точки зрения достижения благополучной эпидемической ситуации, оказались Китай, Тайвань и Южная Корея, а среди европейских стран и стран Северной Америки - Польша, Германия и Норвегия.

\section{ДЕМОГРАФИЧЕСКИЕ И ЭКОНОМИЧЕСКИЕ ФАКТОРЫ ${ }^{1}$}

Рассматриваемые 14 стран изучены по следующим демографическим показателям: плотность населения; медианный возраст населения; ожидаемая продолжительность жизни при рождении (ОПЖ), которую можно рассматривать как обобщенную характеристику здоровья населения (таблица П1). Кроме того, страны проанализированы по уровню ВВП на душу населения, оцененного в долларах США по паритету покупательной способности (\$ ППС; в 2018 г. 1\$ ППС = 24,8 руб.). ВВП - это ключевая макроэкономическая

\footnotetext{
1 Здесь и далее в разделе использованы базы данных: Европейская база данных о смертности / WHO Mortality Database. URL: http://apps.who.int/healthinfo/statistics/mortality/whodpms/; Росстат. URL: http://www.gks.ru/; OECD.Stat / база данных OЭCP. URL: https://stats.oecd.org/; World Bank. URL: https://www.worldbank.org. 
характеристика страны. Все данные представлены по состоянию на 2018 г.

В России плотность населения самая низкая из всех рассматриваемых стран после Канады (рисунок 7).

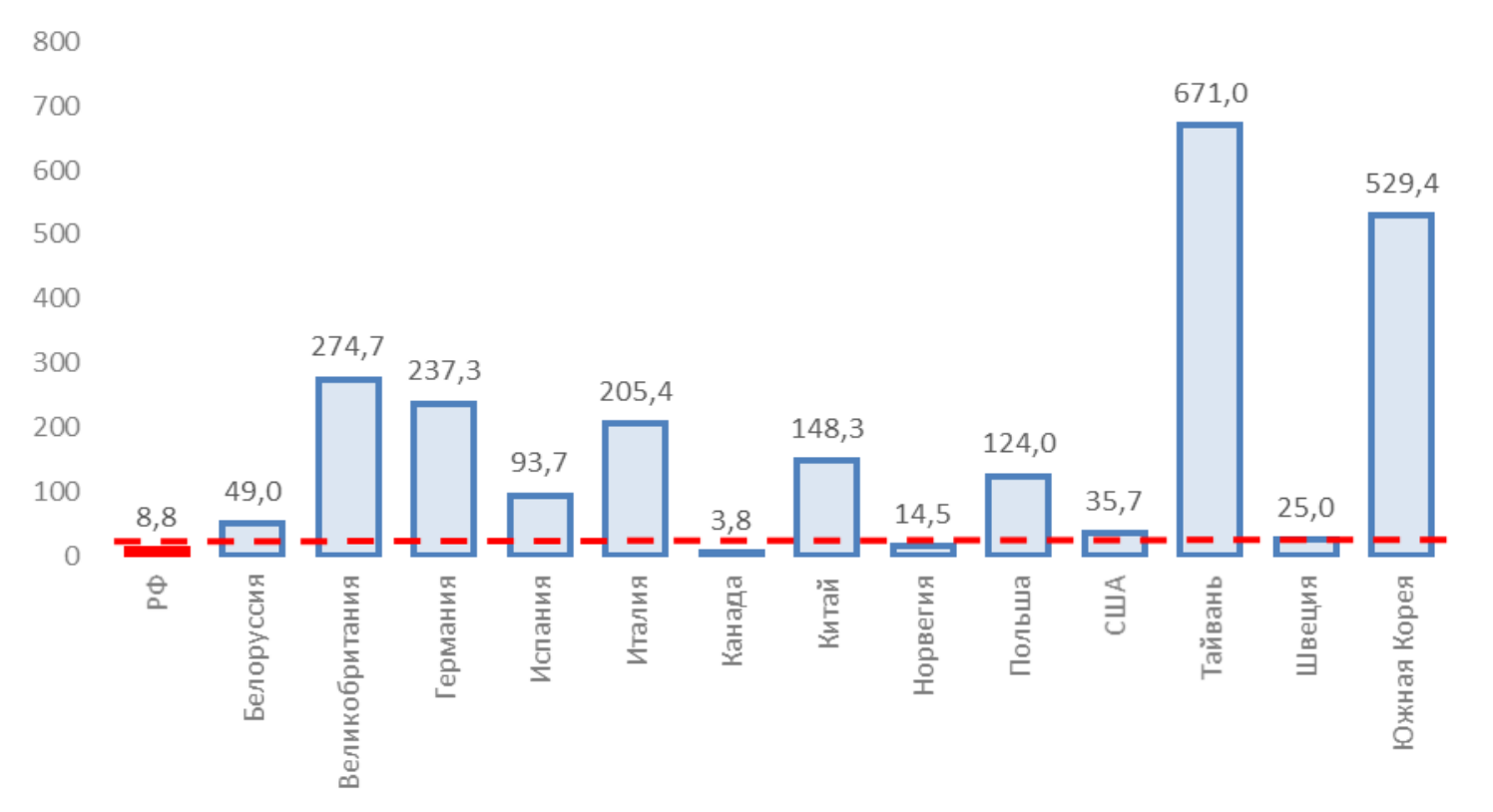

Рисунок 7. Плотность населения в разных странах, чел./км²

Источник: Всемирный банк, база данных «Показатели мирового развития».

Медианный возраст населения России составляет 39,6 года, это почти на уровне Норвегии и Белоруссии, выше, чем в Китае и в США, но значительно меньше, чем в других странах - от 0,9 года в Великобритании до 7,5 года в Германии (рисунок 8).

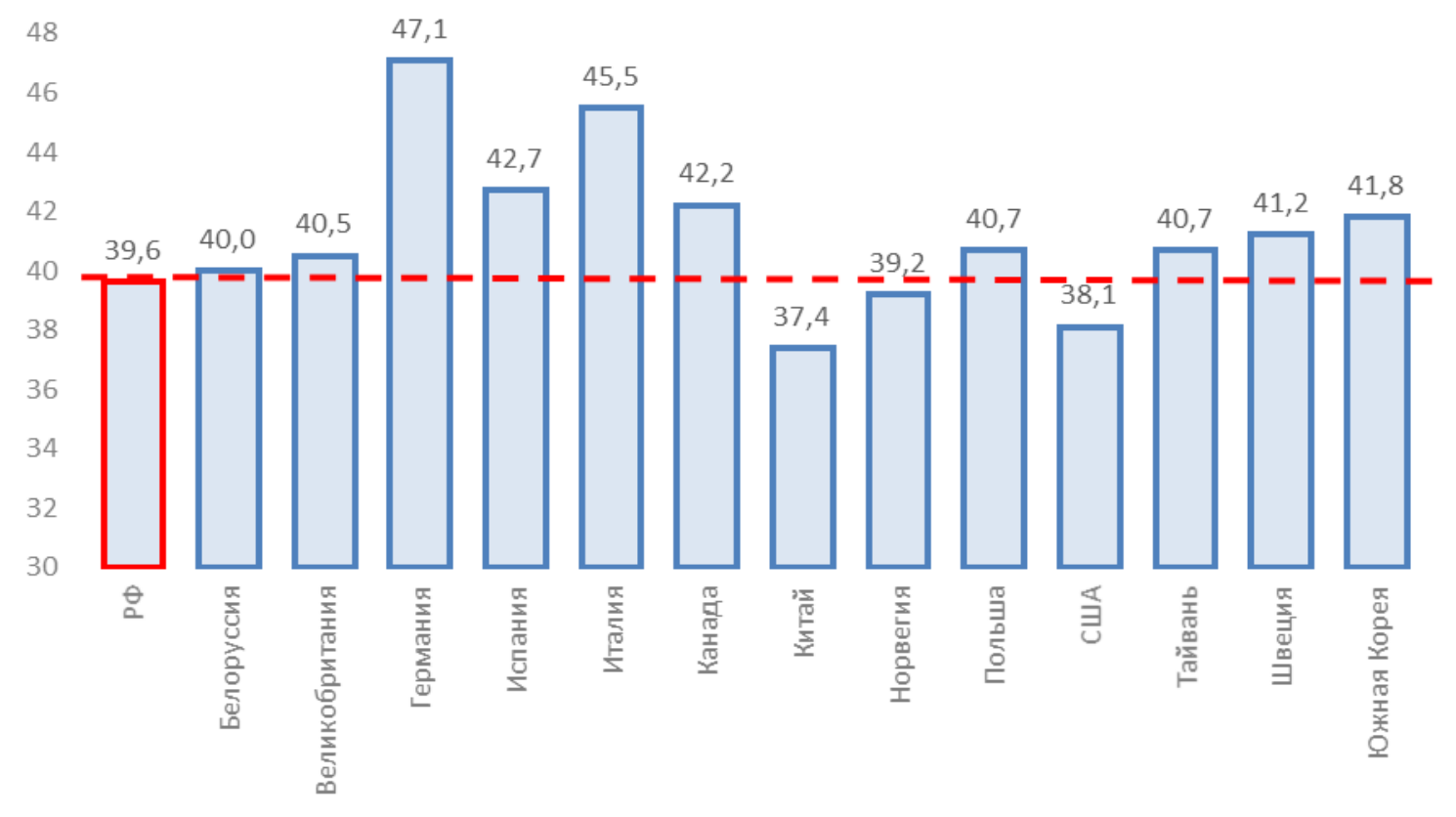

Рисунок 8. Медианный возраст населения в разных странах, лет

Источник: CIA World Factbook. 
Ожидаемая продолжительность жизни в России - самая низкая среди рассматриваемых стран - на 3 года ниже, чем в Китае, и, в среднем, на 8 лет ниже, чем в остальных странах (рисунок 9).

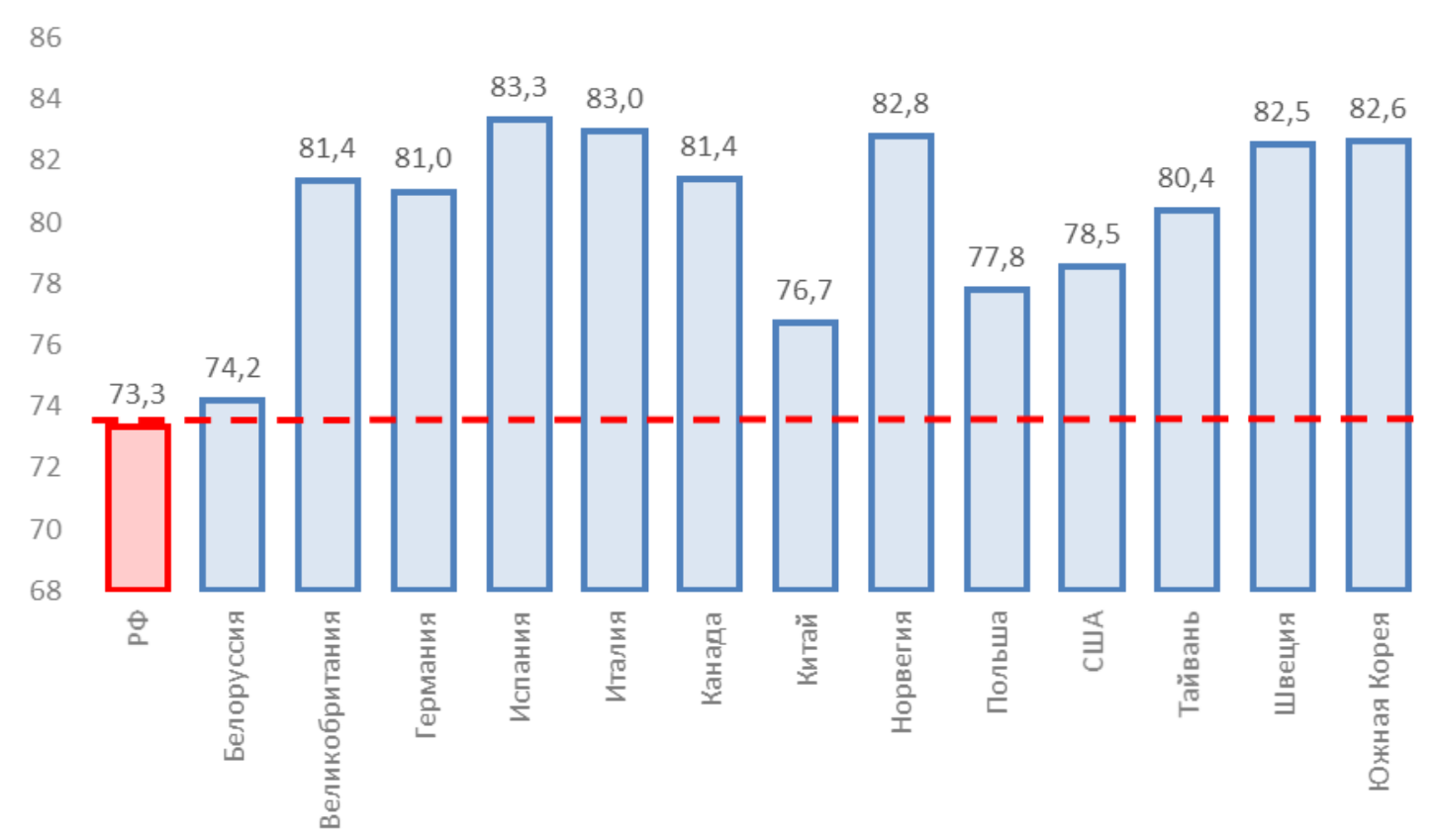

Рисунок 9. Ожидаемая продолжительность жизни в разных странах, лет

Источник: Всемирная организаџия здравоохранения, Росстат.

ВВП на душу населения в России, в среднем, на 30\% ниже, чем в рассматриваемых странах, кроме Китая и Белоруссии (рисунок 10).

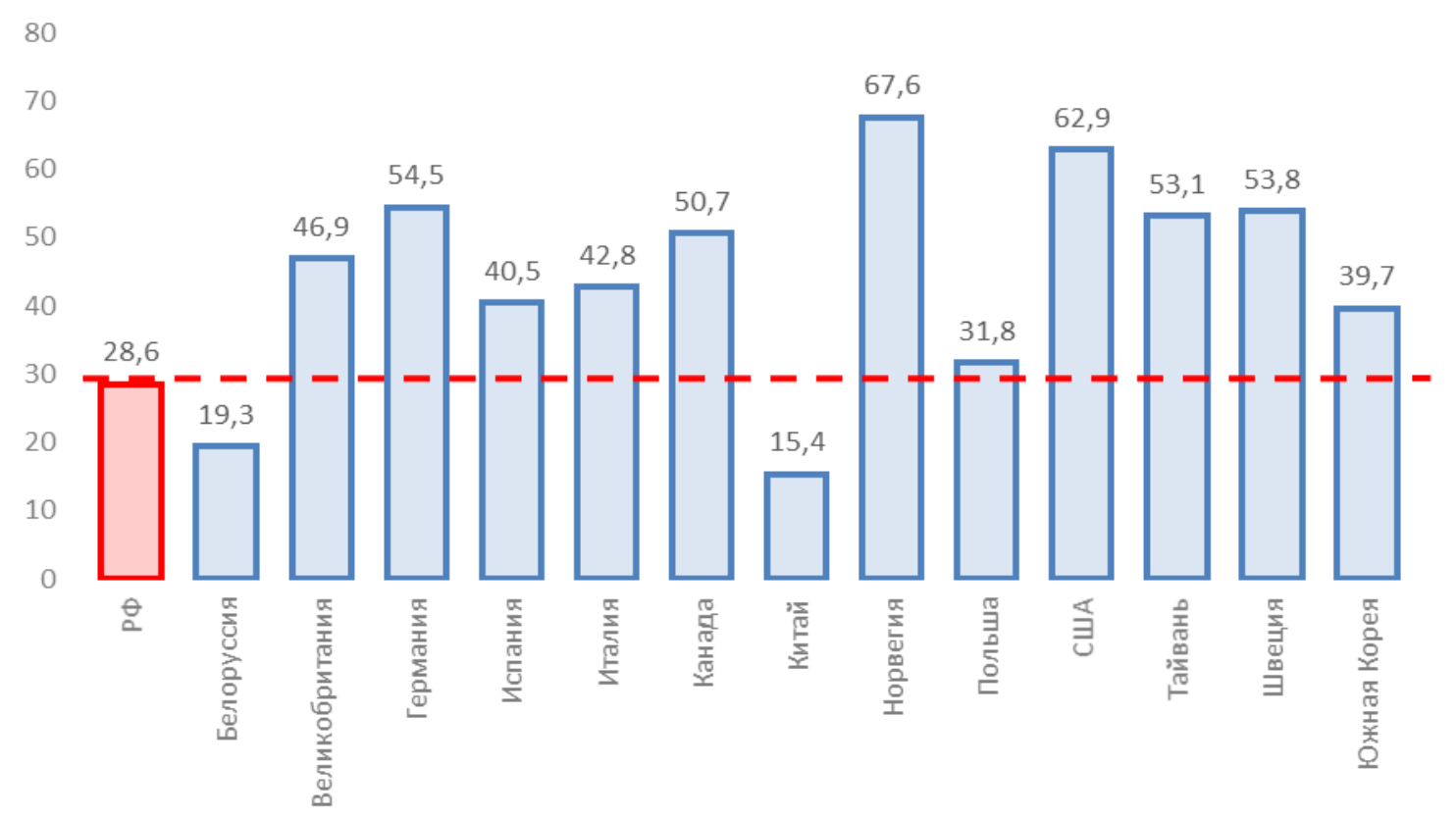

Рисунок 10. Валовой внутренний продукт на душу населения в разных странах, тыс. \$ППС

Источник: Всемирный банк, база данных «Показатели мирового развития». 
Таким образом, к факторам, которые должны были благоприятно сказаться на ограничении распространении инфекции в РФ, можно отнести низкую плотность и более молодой возраст населения. При этом отрицательное влияние могли оказать худшее здоровье населения (низкая ОПЖ) и более низкий уровень экономического развития (ВВП на душу населения).

\section{ХАРАКТЕРИСТИКИ СИСТЕМЫ ЗДРАВООХРАНЕНИЯ}

В рассматриваемых странах изучены следующие показатели состояния системы здравоохранения: доля общих и государственных расходов на здравоохранение в ВВП; обеспеченность стационарными койками и практикующими врачами; модель государственного финансирования здравоохранения и управления отраслью (таблица П1).

В России доля государственных расходов на здравоохранение в ВВП ниже, чем во всех рассматриваемых странах, кроме Китая: в 2,1 раза ниже, чем в Канаде и Великобритании, в 2,5 раза ниже, чем в Норвегии, в 2,7 раза ниже, чем в Германии и Швеции, в 4 раза ниже, чем в США (рисунок 11).

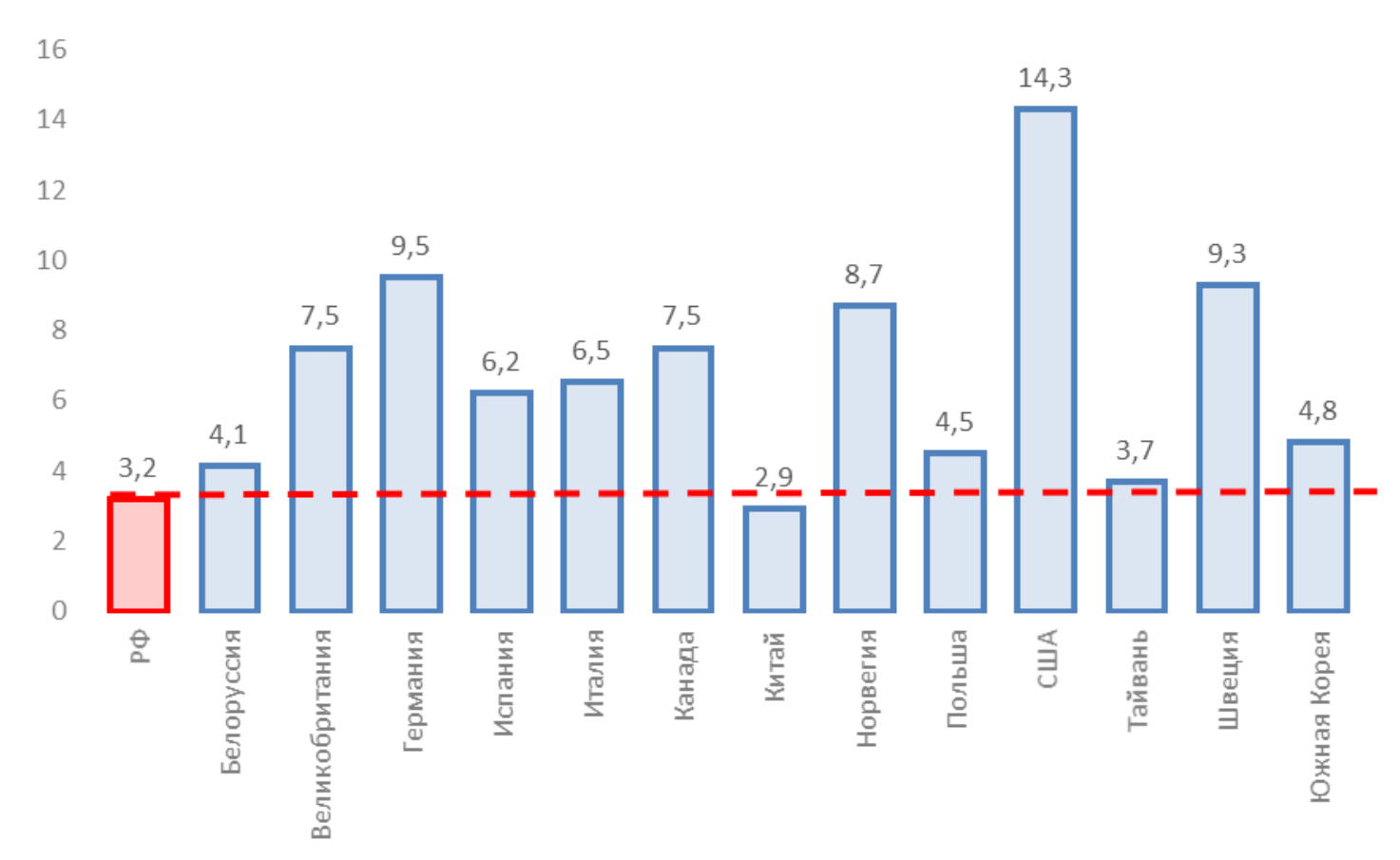

Рисунок 11. Государственные расходы на здравоохранение в разных странах, доля ВВП, \%

Источник: ОЭСР, ВОЗ.

Обеспеченность стационарными койками (без учета коек на ремонте) в расчете на 1000 населения в России выше, чем в ряде европейских стран (Великобритании, Испании, Италии, Норвегии, Швеции), Канаде, США и Китае; соответствующий российский показатель находится на уровне Тайваня, но на $18 \%$ ниже, чем в Германии и Белоруссии, и в 2 раза ниже, чем в Южной Корее (рисунок 12). При сравнении показателей обеспеченности стационарными койками и практикующими врачами в России и в других 
странах необходимо помнить, что в России очень низкая плотность и хуже здоровье населения (ОПЖ существенно ниже, чем в других странах). Из этого следует, что мощности системы здравоохранения, которые определяются этими показателями и обеспечивают доступность медицинской помощи, в РФ должны быть значительно выше, чем в рассматриваемых странах.

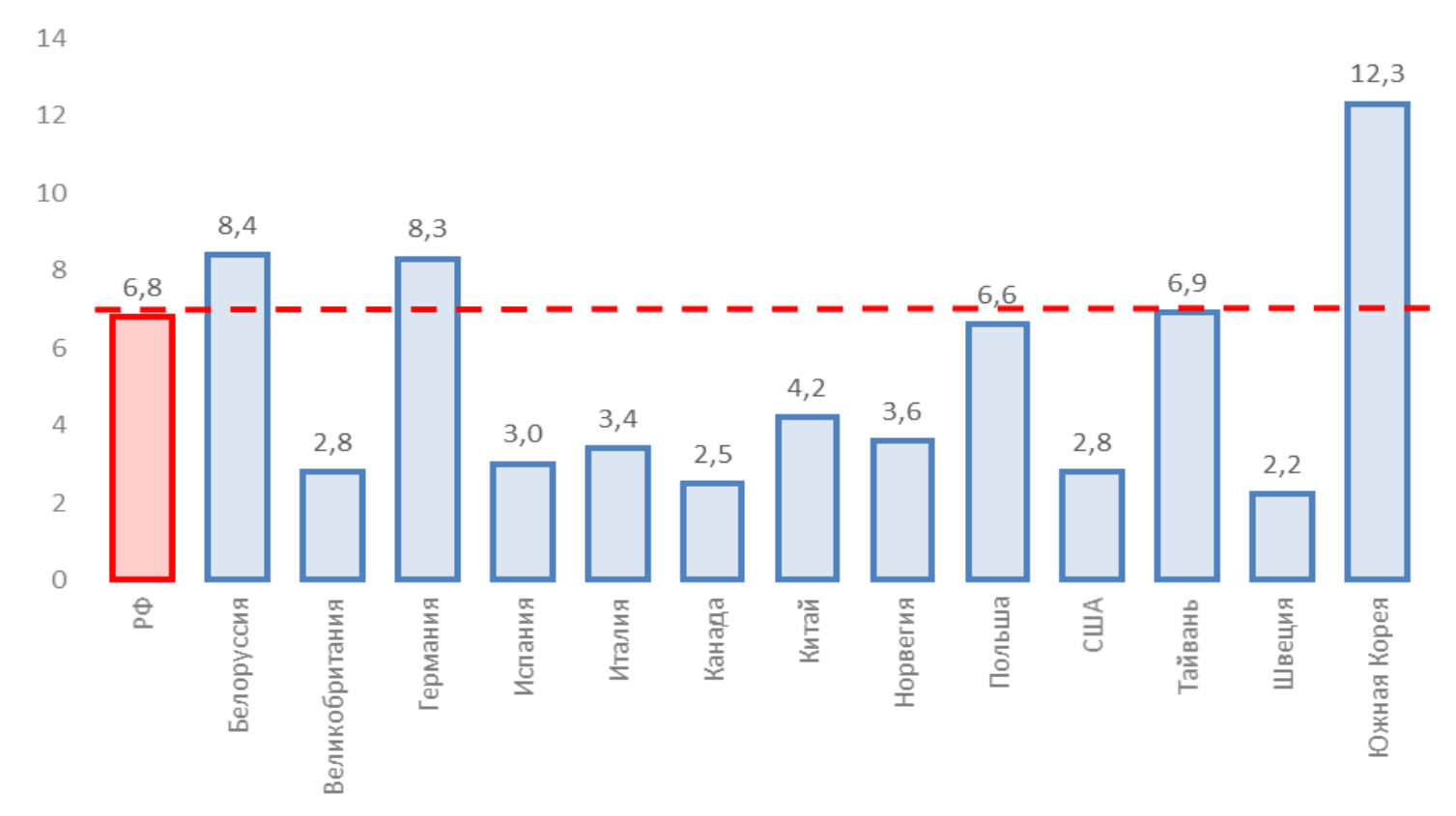

Рисунок 12. Обеспеченность стационарными койками в разных странах, на 1000 населения

Источник: ОЭСР, ВОЗ.

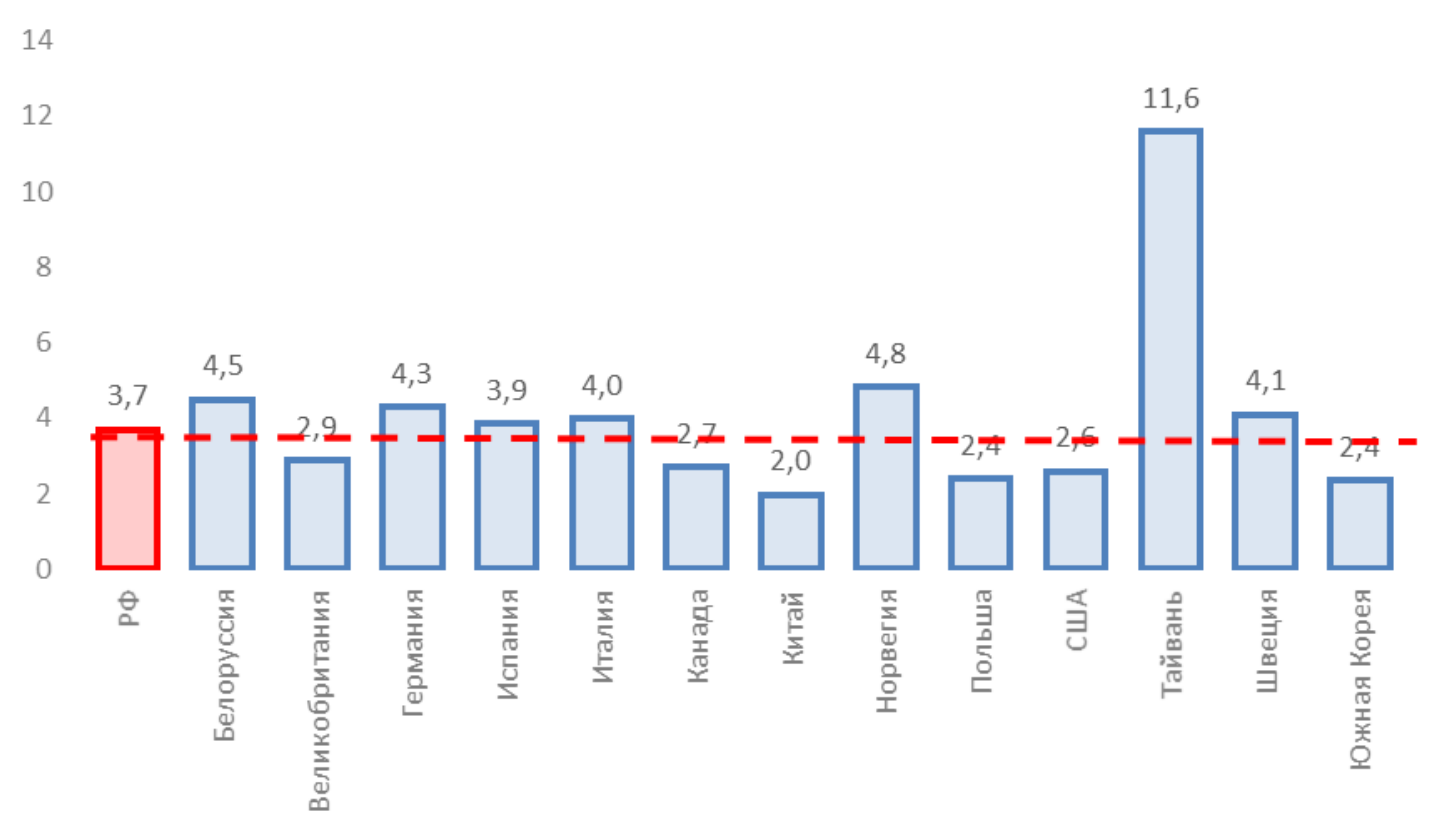

Рисунок 13. Обеспеченность практикующими врачами в разных странах, на 1000 населения

Источник: ОЭСР, ВОЗ. 
Обеспеченность практикующими врачами (без учета врачей санитарноэпидемиологической группы, стоматологов и фармацевтов) в России практически находится на уровне большинства рассматриваемых стран, хотя она на $14 \%$ ниже, чем в Германии и Белоруссии, на 23\% ниже, чем в Норвегии, и в 3,1 раза ниже, чем в Тайване (рисунок 13).

Говоря о моделях финансирования здравоохранения, которые описаны в таблице П-1 (см. Приложение), следует отметить, что в половине из 14 стран сложилась бюджетная модель финансирования здравоохранения, т. е. государственные гарантии финансируются из налогов федерального и регионального уровня. В другой половине стран источником финансирования являются взносы на обязательное медицинское страхование (OMC), из них затем оплачивается медицинская помощь, гарантированная населению государством. В стране может быть несколько страховых компаний (фондов, касс) или один центральный фонд ОМС. Эта модель получила название страховой. В РФ сложилась смешанная модель финансирования здравоохранения ОМС + бюджет, в США тоже действует смешанная модель, только уже бюджет + добровольное медицинское страхование (ДМС). Централизованное управление здравоохранением и его финансированием было во всех странах, которые показали успехи в борьбе с эпидемией (в Китае, Норвегии, Тайване и в Южной Корее), в них также вопросы санитарно-эпидемиологического надзора находились в ведомстве министерств здравоохранения.

\section{МЕРЫ, РЕАЛИЗОВАННЫЕ СТРАНАМИ, ДОБИВШИМИСЯ СУЩЕСТВЕННЫХ УСПЕХОВ В БОРЬБЕ С ИНФЕКЦИЕЙ COVID-19}

Для анализа конкретных мер, реализованных в профилактике и предотвращении распространения новой коронавирусной инфекции COVID-19, из стран Восточной Азии были выбраны Китай, Тайвань и Южная Корея, а из европейских - Норвегия. Следует отметить, что страны Восточной Азии ранее в 2003 г. уже сталкивались со вспышкой серьезной инфекции, вызванной коронавирусом SARS. Этот вирус, как и новый коронавирус SARS-Cov-2, вызывает у зараженных острый респираторный дистресссиндром. Однако он сопровождался более высокой летальностью (11\%), чем нынешний, при котором летальность в среднем по миру составляет 6\%. Предшествующая эпидемия научила эти страны быстро и решительно реагировать на чрезвычайные ситуации. Ниже описаны главные меры, которые они реализовали.

\section{Kumaй}

В начале (в середине января) SARS-CoV-2-эпидемия в Ухане (Китай), где она началась, имела $R_{t}$ от 3 до $4^{2}$ (Inglesby 2020). Другими словами, каждый зараженный передавал

\footnotetext{
${ }^{2}$ URL: https://jamanetwork.com/journals/jama/fullarticle/2765665, $\mathrm{R}_{\mathrm{t}}$ - эффективное репродуктивное число, которое показывает время распространения эпидемии за определенное время $\mathrm{t}$ при наличии контрольных мер и является индикатором для их оценки. Для справки: одна из характеристик распространения вируса это $\mathrm{R}_{\mathrm{o}}$ или ожидаемое число случаев заражения, произведенных первичным зараженным за определенное время. Оно используется для оценки распространения эпидемии среди подверженной данной инфекции популяции (без применения противоэпидемических мер).
} 
инфекцию еще 3-4 другим людям. Это очень большое число; для сравнения: при обычном гриппе, который ежегодно регистрируется в мире, $R_{t}$ варьируется от 1,4 до 1,7 . С учетом того, что время удвоения SARS-CoV-2 составляет 5 дней (т. е. через 5 дней будет заражено $4^{2}$, еще через 5 дней $-4^{2} \times 4$ и так далее, через 30 дней число заражений составит $4^{6}$ ), было очевидно, что эта эпидемия выйдет из-под контроля. А если $R_{t}$ для определенной болезни и локализации снижается <1, это означает, что эпидемию можно взять под контроль.

Жесткие меры. Ухань с населением 11 млн человек стал эпицентром эпидемии в Китае - там было зарегистрировано подавляющее число случаев заражения и смертей из общего числа 84 тыс. зараженных и 4,6 тыс. смертей в этой стране (на 17.06.2020 г.). В ответ на вспышку эпидемии правительство Китая 23 января 2020 г. приняло жесткие меры по ограничению контактов и другие действия по предотвращению распространения инфекции. Среди них закрытие школ и бизнесов, закрытие города и социальные кордоны на въезд в него, полная изоляция граждан на дому, массовое тестирование населения, выявление контактов и их принудительная карантинизация (причем в специально отведенных для этого местах), резкое ограничение передвижения транспорта по городу, дезинфекция общественных мест и транспорта. Это позволило снизить $R_{t}$ эпидемии $<1$ всего за несколько недель: 19 апреля были сняты меры социальной изоляции. В течение апреля и мая в Китае наблюдались только спорадические случаи этой инфекции. Возможно, часть этих мер трудно применить для европейских стран, однако их высокая эффективность очевидна.

В Китае на конец апреля было сделано около 15 млн тестов (ПЦР $)^{3}$, больше, чем в любой другой стране на эту дату. Тем не менее правительство страны приняло решение массово нарастить производство тестовых систем и провести поголовное тестирования жителей Уханя. Оно было проведено в конце мая и продолжалось около 10 дней $^{4}$ Всего было сделано почти 11 млн диагностических тестов (ПЦР), включая 1 млн тестов, сделанных ранее 5 . В результате обнаружено всего 300 случаев асимптоматичного течения инфекции и ни одного случая с симптомами. Дополнительно было протестировано 1200 контактов, ни у одного из них не выявлено наличие инфекции. Это говорило о том, что передача инфекции была остановлена практически полностью. Цена проведения этого исследования - 126 млн долларов США. Впечатляют сроки и масштабы этого начинания. Сегодня в Ухане продолжает соблюдаться масочный режим для общественных мест.

\section{Тайвань'}

Тайвань расположен на расстоянии 150 км от Китая. В стране проживает 23 млн человек, из них 805 тыс. живут в Китае и еще 400 тыс. работают там. В 2019 г. число визитов из Китая в Тайвань достигло 2,7 млн. После вспышки эпидемии в 2003 г., связанной с инфицированием подтипом коронавируса (SARS), в Тайване была создана серьезная служба экстренного реагирования на подобные эпидемии - единый для всей страны Центр

\footnotetext{
${ }^{3}$ URL: https://asia.nikkei.com/Spotlight/Caixin/In-Depth-Widespread-coronavirus-tests-to-be-new-normal-inChina.

${ }^{4}$ URL: http://www.hubei.gov.cn/hbfb/szsm/202006/t20200603_2376356.shtml.

${ }^{5}$ URL: https://www.reuters.com/article/us-health-coronavirus-china-wuhan/no-new-covid-sufferers-300asymptomatic-after-wuhan-wide-tests-idUSKBN23915R.

${ }^{6}$ URL: https://wwwnc.cdc.gov/eid/article/26/7/20-0574_article\#suggestedcitation. 
управления по борьбе с эпидемиями, который входит в состав Национального центра по управлению угрозами здоровью населения (NHCC) (Lin et al. 2020). Главные меры, предпринятые в этой стране, перечислены ниже.

Готовность. Буквально с 1 января 2020 г. началась работа по предотвращению распространения инфекции. 20 января была активирована работа единого Центра по борьбе с эпидемиями во главе с министром здравоохранения (врач по образованию). Он имел полномочия координировать работу в регионах и муниципалитетах, а также других министерств (образования, торговли, экономики, труда, транспорта и др.).

Централизация управления и своевременная мобилизация. Уже с 5 января были организованы медицинское наблюдение и изоляция на 14 дней граждан, прибывающих из Уханя. С 20 января по 7 февраля последовательно вводились меры по ограничению въезда граждан из Китая, Гонконга и Макао, а также были вывезены все туристические группы, прибывшие оттуда. В конце февраля была установлена обязательная карантинизация для граждан, прибывающих из Ирана, Южной Кореи и Италии. Всем с подозрением на инфекцию проводили обследование на 26 типов вирусов. Все организации получили четкие инструкции, как действовать в случае выявления подозрительных и/или подтвержденных случаев коронавируса. Был установлен жесткий контроль за мерами повышенной дезинфекции общественных мест и транспорта, запрещен выезд всех медицинских работников из страны.

Скоординированность действий. На 27-й день от начала эпидемии были объединены базы данных медицинского страхования и миграционного контроля. Все больницы, врачи и аптеки получили доступ к информации о предшествующих заграничных передвижениях граждан с целью выявления возможных зараженных. Всем прибывшим из районов, опасных по эпидемиологической обстановке, выдавали государственные мобильные телефоны, устанавливали обязательную изоляцию на 14 дней и жестко контролировали ее соблюдение. За нарушение изоляции был установлен штраф 5 тыс. долларов США. Сортировку прибывающих по степени риска проводили непосредственно в аэропортах на основании предварительно заполненной электронной формы с использованием QR-кода. На реализацию все этих мер было выделено 2 млрд долларов США.

Публичность. Уже с 20 января правительство Тайваня организовало ежедневные брифинги с населением, на которых выступали вице-президент (эпидемиолог по образованию), министр здравоохранения (врач по образованию) с разъяснением ситуации и рекомендациями. С первых же дней были установлены штраф в размере 100 тыс. долларов США за дезинформацию, работала горячая линия для населения.

Централизация управления производством, закупками и распределением дефицитных ресурсов. Были мобилизованы военные для производства медицинских масок, осуществлялся контроль распределения дефицитных товаров (медицинских масок, дезинфицирующих средств и др.) по медицинским организациям и аптекам. 


\section{Южнная Корея ${ }^{7}$}

В Южной Корее предпринятые меры тоже были решительными, профессиональными и управлялись централизованно (Kim 2020). С учетом уроков прошлых эпидемий (SARS и MERS) в стране были пересмотрены законы, которые позволяют властям немедленно реагировать в критической ситуации: регистрировать необходимые тест-системы, быстро вводить карантин и отслеживать контакты зараженных

Система ответа на критические ситуации в Корее имеет 4 уровня. Уже 3 января 2020 г. был принят голубой уровень, 20 января - желтый, 28 января - оранжевый, 23 февраля - красный уровень (чрезвычайное положение). 28 января было создано Центральное управление по борьбе с чрезвычайными ситуациями во главе с министром здравоохранения и социального развития. При достижении красного уровня правительство Кореи создало верховную ставку центрального управления во главе с премьер-министром для координации работы разных министерств в борьбе с эпидемией. Министр здравоохранения стал его первым заместителем, министр внутренних дел - вторым заместителем. В регионах создавались аналогичные органы управления во главе с их главами.

Центр по контролю и профилактике заболеваний (аналог Роспотребнадзора в РФ), находящийся в структуре Министерства здравоохранения, выполнял функции по мониторингу данных и подготовке научной информации в борьбе с инфекцией. С учетом опыт прошлых эпидемий, глава Центра по профилактике и борьбе с инфекционными заболеваниями был сразу назначен заместителем министра здравоохранения.

Информирование населения и прозрачность. Министр здравоохранения и глава центра по контролю и профилактике заболеваний дважды в день (!) лично проводили брифинги с прессой.

Массовое тестирование и отслеживание контактов. Были немедленно сертифицированы частные лаборатории по проведению тестирования и организованы массовые центры по тестированию как в государственных медицинских организациях, так и вне стен лечебных учреждений.

После выявления зараженные получали смс-сообщение на телефон, далее проводилась дезинфекция помещения, где они до этого находились. 7 раз в день население оповещали о новых зараженных с помощью смс-сообщений. 27 января уже были разработаны все необходимые тест-системы для определения инфекции, а 31 января зарегистрирована первая тест-система, разработанная биотехнологической компанией.

Специальные центры (по общественному здоровью) отслеживали контакты зараженных через информационную систему, основанную на транзакциях банковских карт, и по GPS-отслеживанию через мобильные телефоны зараженных. Все подозрительные контакты подвергали принудительному карантину. Для этого было разработано специальное мобильное приложение, которое позволяло дважды в день отслеживать

\footnotetext{
${ }^{7}$ URL: https://www.tandfonline.com/doi/full/10.1080/14719037.2020.1766266. 
соблюдение карантина и состояние изолированного гражданина. Все данные по регионам отслеживали в режиме реального времени - к концу февраля была создана единая электронная база данных по мониторингу, позволяющая получать информацию по контактам в течение 10 мин.

Эффективная организация медицинской помощи. Все случаи заболевших классифицировали на 4 категории в зависимости от тяжести заболевания, исходя из этого их распределяли в лечебные учреждения, где они получали разное лечение. Случаи средней тяжести, тяжелых и очень тяжелых пациентов сразу же госпитализировали в специальные инфекционные больницы или специально определенные правительством медицинские центры. Легкие случаи наблюдались на дому медицинским персоналом дважды в день. Для каждого случая были свои протоколы лечения.

Больницы были поделены на те, которые занимались лечением пациентов с COVID19, и «чистые», в последних жестко разделяли потоки пациентов с респираторными заболеваниями и без них. Централизованное управление позволяло распределять медицинский персонал и средства защиты в зависимости от нуждаемости регионов. Данные с рентгеновских снимков передавали в единый центр за секунды, диагностику проводили с использованием искусственного интеллекта в едином для страны центре.

Достаточный коечный фонд (12,2 на 1000 населения) позволил спокойно перепрофилировать стационарные койки под оказание помощи инфекционным пациентам без ущерба оказания помощи пациентам с другими заболеваниями.

\section{Норвегия ${ }^{8}$}

Норвегию характеризуют следующие действия по предотвращению распространения эпидемии: быстрое реагирование и организация централизованного управления (Mjaset 2020). В конце января в Норвегии был создан штаб по борьбе с эпидемией во главе с министром здравоохранения, который передал часть оперативных полномочий Директорату общественного здоровья (аналог Роспотребнадзора в РФ). Все муниципалитеты были предупреждены и действовали в едином ключе. С первых дней началось массовое тестирование на выявление зараженных (приезжие из Китая, Италии, пациенты с респираторными симптомами и все контакты заболевших).

Тогда же была разработана Национальная стратегия борьбы с эпидемией, закуплены на централизованном уровне средства индивидуальной защиты (СИЗ), расходные материалы для тест-систем и другие необходимые товары. Все больницы через региональные правительства передавали в центральный штаб информацию о наличии СИЗ и лекарств. В закупку необходимых товаров за рубежом было вовлечено Министерство иностранных дел, необходимые лекарства и расходные материалы доставлялись немедленно. Министерство обороны проверяло прибывающий товар на соответствие уровню качества.

\footnotetext{
${ }^{8}$ URL: https://catalyst.nejm.org/doi/full/10.1056/CAT.20.0120.
} 
Во многом слаженный эффект системы здравоохранения Норвегии был обеспечен единой бюджетной системой финансирования медицинской помощи, быстрым реагированием правительства и наличием национальной стратегии. 6 апреля, когда многие страны еще находились на пике эпидемии, ситуация в Норвегии была стабилизирована.

\section{Российская Федерация}

В России в борьбе с эпидемией были приняты меры, близкие к тем, которые были приняты во всех других европейских странах: социальная изоляция граждан, закрытие школ и бизнесов, отмена авиарейсов и общественных мероприятий. Российской системе здравоохранения в течение месяца удалось развернуть более 100 тыс. коек для лечения пациентов с COVID-19. Были приняты меры по расширению объемов диагностического тестирования: в мае уже проводилось свыше 115 тыс. тестов в день (по данным Роспотребнадзора на начало мая 2020 г.). Несмотря на это, через 2 месяца после начала изоляции в стране до сих пор не наблюдается снижения числа случаев инфицированных, т.е. $R_{t}$ пока не упало ниже 1 , ежедневно регистрируется около 8 тыс. новых случаев.

Однако следует отметить, что в РФ управление здравоохранением регионов было децентрализовано, службы санэпиднадзора (Роспотребнадзор) не подчинялись Минздраву России, централизованного мониторинга и управления распределением СИЗ и других расходных материалов и медицинского оборудования установлено не было. Судя по письмам врачей из регионов, наблюдалась нехватка финансирования в медицинских организациях, которые не были вовлечены в оказание помощи при инфекции (из-за отмены госпитализации и приема пациентов, не страдающих COVID-19).

\section{Выводы}

Из рассматриваемых 14 стран (Белоруссия, Великобритания, Германия, Испания, Италия, Канада, Китай, Норвегия, Польша, Россия, США, Тайвань, Швеция и Южная Корея) по состоянию на 17 июня 2020 г. самыми успешными в достижении благоприятной эпидемической ситуации по новой коронавирусной инфекции COVID-19 оказались страны Восточной Азии (Китай, Тайвань, Южная Корея), а также Норвегия. В этих странах самые низкие показатели числа инфицированных в расчете на 1 млн населения и число смертей на 100 тыс. населения. Сегодня там практически нет новых случаев вновь зараженных и умерших от этой инфекции. Причем стабилизации ситуации по эпидемии этим странам удалось добиться еще в апреле. И это несмотря на очень высокую плотность и более старший возраст населения по сравнению с Россией и другими странами.

В России оценить эпидемическую ситуацию по новой коронавирусной инфекции COVID-19 по сравнению с европейскими странами, США и Канадой можно как среднюю. По общему числу зараженных РФ находиться на 2-м месте после США, по числу зараженных в расчете на 1 млн населения - на 7-м месте, по числу умерших на 100 тыс. населения - на 4-м, разделяя его с Норвегией. Возможно, более высокие показатели числа зараженных в РФ связаны с высоким уровнем тестирования (в РФ оно самое высокое в 
расчете на 1000 населения по сравнению с другими странами). Однако пока9 в нашей стране не снижаются ежедневное число случаев вновь зараженных (около 8 тыс.) и число умерших. Следует отметить, что в РФ наблюдается непропорционально низкое по сравнению с другими странами число умерших (летальность на 20\% ниже, чем в Тайване, в 2 раза ниже, чем в Норвегии, и от 3 до 10 раз ниже, чем в других странах). Такие расхождения говорят о разной системе учета и регистрации смертей.

Анализ демографических, экономических показателей и характеристик системы здравоохранения показал, что в РФ, по сравнению с исследуемыми странами, имеется целый ряд факторов, которые отрицательно сказались на готовности к эпидемии. Среди них худшие показатели здоровья населения (ожидаемая продолжительность жизни в нашей стране на $\geq 3$ года ниже, чем в других странах); низкий ВВП на душу населения (на $\geq 30 \%$ ниже); существенно меньшие государственные расходы на здравоохранение (в $\geq 2$ раз ниже), низкая обеспеченность медицинскими кадрами (по сравнению с Белоруссией, Германией, Тайванем и Норвегией) и стационарными койками (по сравнению с Белоруссией, Германией, Тайванем и Южной Кореей). Дополнительным неблагоприятным фактором для России является децентрализованная система управления здравоохранением.

Общие характеристики, которые отличали страны, успешные в борьбе с эпидемией:

- раннее реагирование и решительные действия;

- централизация управления регионами и санитарно-эпидемиологической службой во главе с министром здравоохранения;

- наличие единой для страны стратегии действий;

- проведение массового тестирования и быстрое отслеживание контактов зараженных;

- централизованное распределение СИЗ, лекарств и других расходных материалов, а также мониторинг потребности в них;

- использование передовых информационных технологий, единые достоверные базы данных и отчетности;

- достаточные мощности системы здравоохранения (наличие резервного коечного фонда и медицинских кадров);

- ежедневная информационная работа с населением, которая осуществлялась специалистами и министром здравоохранения.

\section{Рекомендации для РФ по реформе системы здравоохранения для обеспечения ее устойчивости в обычное время и при возникновении чрезвычайных ситуаций}

- Восстановить централизованную систему управления здравоохранением в стране во главе с Минздравом России, в том числе подчинить ему все службы, отвечающие за безопасность здоровья населения, включая Всероссийский центр медицины катастроф «Защита».

\footnotetext{
${ }^{9}$ На момент написания статьи.
} 
- Увеличить государственные расходы на здравоохранение с 3,5 до 6\% ВВП 2019 г. ${ }^{10}$ (с 3,8 до 6,5 трлн руб. к 2022 г. в ценах 2019 г.). Ежегодно дополнительно потребуется около 1 трлн руб., начиная с 2020 г.

- Восстановить бюджетное финансирование системы здравоохранения. Для этого средства ОМС, федерального и региональных бюджетов должны быть объединены у единого плательщика с последующим перераспределением в регионы исходя из их сбалансированных потребностей.

- Восстановить оплату медицинских организаций по смете, которая покрывает их базовые расходы, соответственно обеспечивает их деятельность вне зависимости от потока пациентов и установленных тарифов. Расположение и мощности этих организаций должны быть обоснованы исходя из потребностей населения в медицинской помощи и ее территориальной доступности. Это позволит сохранить медицинские организации в сельской местности, малых городах, восстановить инфекционную службу и скорую медицинскую помощь.

- Исправить положение медицинских работников, для чего установить на федеральном уровне единые базовые оклады по основным квалификационным группам и льготы для них, такие же, как для военных и персонала Росгвардии. Это позволит ликвидировать дефицит медицинских кадров и повысить обеспеченность ими.

- Обеспечить качество медицинского образования и развитие медицинской науки, в том числе создать условиях для обеспечения непрерывного медицинского образования, установить оплату труда профессорскопреподавательского состава медицинских вузов и колледжей (базовые оклады) в 2 раза выше, чем у практикующих врачей и медицинских сестер, увеличить финансирование медицинской науки в 3 раза от существующего уровня (с 0,04 до 0,12\% ВВП; для справки: в развитых странах -0,3-0,4\% ВВП).

- Обеспечить постоянную готовность к эпидемиям и другим чрезвычайным ситуациям, для чего воссоздать под руководством Минздрава России систему постоянной готовности к чрезвычайным ситуациям (катастрофам, эпидемиям), в том числе разработать государственную программу действий при чрезвычайных ситуациях, проводить учения и публиковать государственный отчет по установленным показателям, рассчитать и создать резервы коечных мощностей, подготовленных медицинских кадров (которые можно быстро мобилизовать), запасов СИЗ и других расходных материалов, выделить специальное финансирование по этим статьям. Оперативный центр должен находиться в Минздраве России и обладать полномочиями ежедневного проведения оперативных совещаний со СМИ и координации работы смежных ведомств.

${ }^{10}$ Цены 2019 г. указаны специально, чтобы дополнительные средства, направленные на здравоохранение, не обесценивались инфляцией. 


\section{ЛИТЕРАТУРА}

Inglesby T.V. (2020). Public health measures and the reproduction number of SARS-CoV-2. Jama. DOI: https://doi.org/10.1001/jama.2020.7878 Online ahead of print.

Kim P.S. (2020). South Korea's fast response to coronavirus disease: implications on public policy and public management theory. Public Manag Rev, 1-12.

Lin C., Braund W. E., Auerbach J., Chou J.H., Teng J.H., Tu P., Mullen J. (2020). Policy decisions and use of information technology to fight 2019 novel coronavirus disease, Taiwan. Emerging Infectious Diseases, 26(7).

Mjaset C. (2020). On Having a National Strategy in a Time of Crisis: Covid-19 Lessons from Norway. NEJM Catalyst Innovations in Care Delivery, 1 (3). 


\section{ПРИЛОЖЕНИЕ}

\section{Таблица П-1. Демографические, географические и социально-экономические характеристики некоторых стран мира}

\begin{tabular}{|c|c|c|c|c|c|c|c|c|c|c|c|c|c|c|}
\hline Показатели / Страна & Россия & $\begin{array}{l}\text { Бело- } \\
\text { руссия }\end{array}$ & $\begin{array}{l}\text { Велико- } \\
\text { британия }\end{array}$ & Германия & Испания & Италия & Канада & Китай & Норвегия & Польша & США & Тайвань & Швеция & $\begin{array}{l}\text { Южная } \\
\text { Корея }\end{array}$ \\
\hline Население, млн чел. & 147 & 9 & 66 & 83 & 47 & 60 & 38 & 1393 & 5 & 38 & 327 & 24 & 10 & 52 \\
\hline $\begin{array}{l}\text { Медианный возраст населения, } \\
\text { лет }\end{array}$ & 39,6 & 40,0 & 40,5 & 47,1 & 42,7 & 45,5 & 42,2 & 37,4 & 39,2 & 40,7 & 38,1 & 40,7 & 41,2 & 41,8 \\
\hline ОПЖ при рождении, лет & 73,3 & 74,2 & 81,4 & 81,0 & 83,3 & 83,0 & 81,4 & 76,7 & 82,8 & 77,8 & 78,5 & 80,4 & 82,5 & 82,6 \\
\hline $\begin{array}{l}\text { Плотность населения, человек на } \\
\text { км² }^{2}\end{array}$ & 9 & 49 & 275 & 237 & 94 & 205 & 4 & 148 & 15 & 124 & 36 & 671 & 25 & 529 \\
\hline $\begin{array}{l}\text { ВВП на душу населения, тыс. } \\
\text { \$ПП }\end{array}$ & 28,6 & 19,3 & 46,9 & 54,5 & 40,5 & 42,8 & 50,7 & 15,4 & 67,6 & 31,8 & 62,9 & 53,1 & 53,8 & 39,7 \\
\hline $\begin{array}{l}\text { Общие расходы на } \\
\text { здравоохранение (частные и } \\
\text { государственные) в \% от ВВП }\end{array}$ & 5,1 & 5,9 & 9,8 & 11,2 & 8,9 & 8,8 & 10,7 & 5,2 & 10,2 & 6,5 & 16,9 & 6,3 & 11,0 & 8,1 \\
\hline $\begin{array}{l}\text { Государственные расходы на } \\
\text { здравоохранение, доля от ВВП, \% }\end{array}$ & 3,2 & 4,1 & 7,5 & 9,5 & 6,2 & 6,5 & 7,5 & 2,9 & 8,7 & 4,5 & 14,3 & 3,7 & 9,3 & 4,8 \\
\hline $\begin{array}{l}\text { Обеспеченность стационарными } \\
\text { койками, на } 1000 \text { чел. населения } \\
\text { (без учета коек на ремонте) }\end{array}$ & 6,8 & 8,4 & 2,8 & 8,3 & 3,0 & 3,4 & 2,5 & 4,2 & 3,6 & 6,6 & 2,8 & 6,9 & 2,2 & 12,3 \\
\hline $\begin{array}{l}\text { Обеспеченность практикующими } \\
\text { врачами (без учета стоматологов, } \\
\text { сан-эпид. группы, фармацевтов) }\end{array}$ & 3,7 & 4,5 & 2,9 & 4,3 & 3,9 & 4,0 & 2,7 & 2,0 & 4,8 & 2,4 & 2,6 & 11,6 & 4,1 & 2,4 \\
\hline $\begin{array}{l}\text { Общее число выявленных случаев } \\
\text { Covid-19 }\end{array}$ & 545458 & 55369 & 298136 & 187184 & 244328 & 237500 & 99456 & 84422 & 8631 & 30195 & 2137731 & 445 & 53323 & 12198 \\
\hline $\begin{array}{l}\text { Число выявленных случаев Covid- } \\
19 \text { в расчете на } 1 \text { млн чел. }\end{array}$ & 3715 & 5838 & 4486 & 2258 & 5221 & 3931 & 2631 & 61 & 1625 & 795 & 6544 & 19 & 5240 & 236 \\
\hline $\begin{array}{l}\text { Число проведенных тестов всего, } \\
\text { млн }\end{array}$ & 15,7 & 0,8 & 4,0 & 4,7 & 3,1 & 4,7 & 2,2 & 26,0 & 0,3 & 1,0 & 23,8 & 0,075 & 0,39 & 1,1 \\
\hline $\begin{array}{l}\text { Число проведенных тестов на } \\
1000 \text { населения }\end{array}$ & 106,8 & 80,2 & 60,7 & 56,6 & 65,4 & 77,7 & 58,6 & 18,7 & 55,1 & 25,5 & 72,7 & 3,2 & 37,9 & 22,0 \\
\hline $\begin{array}{l}\text { Число проведенных тестов в } \\
\text { расчете на } 1 \text { инфицированного }\end{array}$ & 28,7 & 13,7 & 13,5 & 25,1 & 12,5 & 19,8 & 22,3 & 308,0 & 33,9 & 32,0 & 11,1 & 167,9 & 7,2 & 92,9 \\
\hline $\begin{array}{l}\text { Общее число умерших от } \\
\text { Covid-19 }\end{array}$ & 7284 & 318 & 41969 & 8830 & 27136 & 34405 & 8213 & 4644 & 242 & 1272 & 116963 & 7 & 4939 & 279 \\
\hline Летальность от Covid-19, \% & 1,3 & 0,6 & 14,1 & 4,7 & 11,1 & 14,5 & 8,3 & 5,5 & 2,8 & 4,2 & 5,5 & 1,6 & 9,3 & 2,3 \\
\hline $\begin{array}{l}\text { Смертность от Covid-19 на } 100 \\
\text { тыс. чел. }\end{array}$ & 5,0 & 3,4 & 63,1 & 10,7 & 58,0 & 56,9 & 21,7 & 0,3 & 4,6 & 3,3 & 35,8 & 0,0 & 48,5 & 0,5 \\
\hline Число умерших за 17.06.2020 г. & 193 & 6 & 233 & 30 & - & 34 & 38 & 6 & - & 16 & 836 & - & 48 & 1 \\
\hline
\end{tabular}




\begin{tabular}{|c|c|c|c|c|c|c|c|c|c|c|c|c|c|c|}
\hline Показатели / Страна & Россия & $\begin{array}{l}\text { Бело- } \\
\text { руссия }\end{array}$ & $\begin{array}{l}\text { Велико- } \\
\text { британия }\end{array}$ & Германия & Испания & Италия & Канада & Китай & Норвегия & Польша & США & Тайвань & Швеция & $\begin{array}{c}\text { Южная } \\
\text { Корея }\end{array}$ \\
\hline $\begin{array}{l}\text { Число умерших в среднем за } \\
\text { последние } 4 \text { дня (13.06.2020 - } \\
17.06 .2020)\end{array}$ & 142 & 5 & 122 & 12 & - & 46 & 41 & 2 & - & 13 & 574 & - & 21 & 1 \\
\hline $\begin{array}{l}\text { Модель финансирования } \\
\text { здравоохранения (ОМС - из } \\
\text { страховых взносов и через фонды } \\
\text { ОМС или бюджетная - из } \\
\text { налогов) }\end{array}$ & 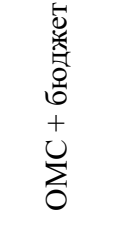 & 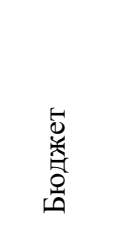 & 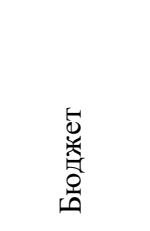 & $\sum_{0}^{U}$ & 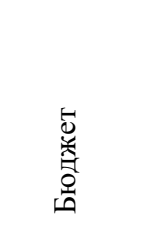 & 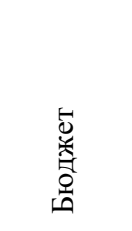 & 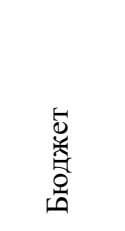 & $\sum_{0}^{0}$ & 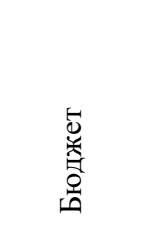 & $\sum_{0}^{0}$ & 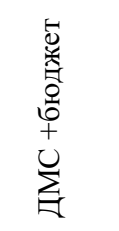 & $\sum_{0}^{U}$ & $\begin{array}{l}\text { 氙 } \\
\text { 悹 } \\
\text { 号 }\end{array}$ & $\sum_{0}^{0}$ \\
\hline $\begin{array}{l}\text { Управление здравоохранением и } \\
\text { его финансированием }\end{array}$ & 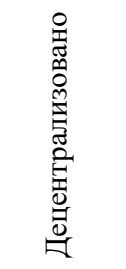 & 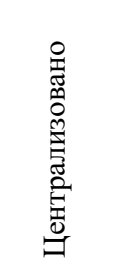 & 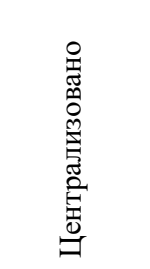 & 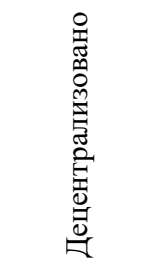 & 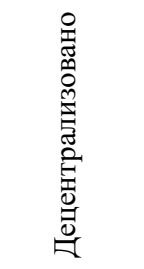 & 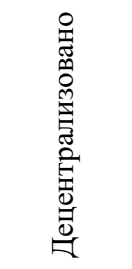 & 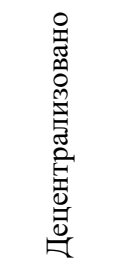 & 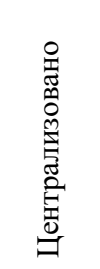 & 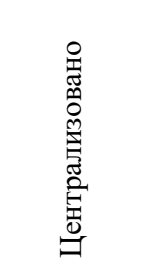 & 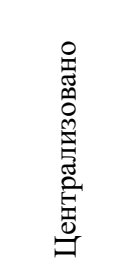 & 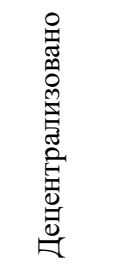 & 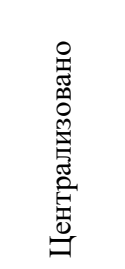 & 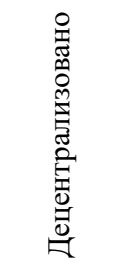 & 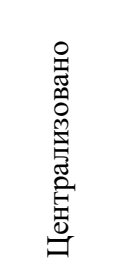 \\
\hline
\end{tabular}

Источник: Составлено авторами на основе данных ВОЗ, Всемирного банка и ОЭСР. 


\title{
HEALTHCARE RESPONSES TO COVID-19 IN DIFFERENT COUNTRIES
}

\author{
GUZEL UlumbEKOVA, ARGISHTI GHINOYAN, IVAN PETRACHKOV
}

\begin{abstract}
This paper aims to identify the social, economic and demographic factors, as well as the health system characteristics and immediate actions taken to combat new COVID-19 coronavirus infection, which contributed to the rapid stabilization of the epidemic situation in different countries. Fourteen countries were chosen for comparison: Belarus, Great Britain, Germany, Spain, Italy, Canada, China, Norway, Poland, the United States, the Russian Federation, Taiwan, Sweden and South Korea. To carry out our task we first analyzed the epidemic indicators (the number of detected COVID-19 cases per one million people, the lethality and mortality from the infection per 100,000 people, the number of diagnostic tests performed), then the demographic (average age of the population, population density, life expectancy) and economic indicators (gross domestic product-GDP per capita), and then assessed the healthcare system (total and state expenses on public health in GDP share; the availability of inpatient beds and practitioners; the model of public health financing and management). It is shown that the main factors of a successful fight against the spreading of COVID-19 are: early response and decisive actions; centralized management of regions and the sanitary-epidemiological service led by the Minister of Health; a nationwide unified action plan; mass testing and rapid contact tracing; the centralized distribution of personal protective equipment (PPE), medicines and other supplies, along with monitoring of the demand for them; the use of advanced information technologies; sufficient capacity of the healthcare system (availability of reserve bed capacity and medical staff); briefings with the population carried out by experts and the Minister of Health.
\end{abstract}

Key words: COVID-19 pandemic, COVID-19 lethality and mortality, COVID-19 diagnostic testing, actions to fight against the COVID-19 pandemic, public health financing, availability of inpatient beds, availability of medical practitioners, centralization of health management.

GuZEL UlumbeKova (vshouz@vshouz.ru), Graduate School of HEALTHCARE ORganization AND MANAGEMENT Complex Medical Consulting (VSHOUZ-KMK), Pirogov Russian National Research Medical University (RNRMU), RUSSIA.

Argishti Ghinoyan (agrio1q89@ hotmail.com), Graduate SchOol of HeAlTHCARE ORGANIZATION AND MANAGEMENT - COMPleX MEDiCAl CONSUlting (VSHOUZ-KMK), FinANCIAL UNIVERSiTY UNDER THE GOVERNMENT OF THE RUSSIAN FEDERATION, RUSSIA.

Ivan Petrachkov (ecrb2007@yandex.ru), Graduate School of HealthCARE ORganization ANd ManagemEnT COMPLEX MEdicAl CONSUlting (VSHOUZ-KMK), RusSiA.

DATE RECEIVED: JUNE 2020.

\section{REFERENCES}

Inglesby T.V. (2020). Public health measures and the reproduction number of SARS-CoV-2. Jama. DOI: https://doi.org/10.1001/jama.2020.7878 Online ahead of print.

Kim P.S. (2020). South Korea's fast response to coronavirus disease: implications on public policy and public management theory. Public Manag Rev, 1-12.

Lin C., Braund W. E., Auerbach J., Chou J.H., Teng J.H., Tu P., Mullen J. (2020). Policy decisions and use of information technology to fight 2019 novel coronavirus disease, Taiwan. Emerging Infectious Diseases, 26(7). 
Mjaset C. (2020). On Having a National Strategy in a Time of Crisis: Covid-19 Lessons from Norway. NEJM Catalyst Innovations in Care Delivery, 1 (3). 